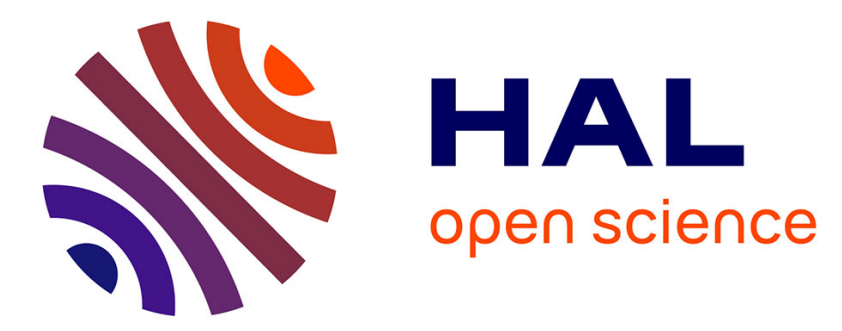

\title{
Thermo-mechanical effects in drilling using metal working fluids and cryogenic cooling and their impact in tool performance
}

José Outeiro, Pierrick Lenoir, A. Bosselut

\section{- To cite this version:}

José Outeiro, Pierrick Lenoir, A. Bosselut. Thermo-mechanical effects in drilling using metal working fluids and cryogenic cooling and their impact in tool performance. Production Engineering, 2015, pp.1-12. 10.1007/s11740-015-0619-6 . hal-01187319

\section{HAL Id: hal-01187319 \\ https://hal.science/hal-01187319}

Submitted on 26 Aug 2015

HAL is a multi-disciplinary open access archive for the deposit and dissemination of scientific research documents, whether they are published or not. The documents may come from teaching and research institutions in France or abroad, or from public or private research centers.
L'archive ouverte pluridisciplinaire HAL, est destinée au dépôt et à la diffusion de documents scientifiques de niveau recherche, publiés ou non, émanant des établissements d'enseignement et de recherche français ou étrangers, des laboratoires publics ou privés. 


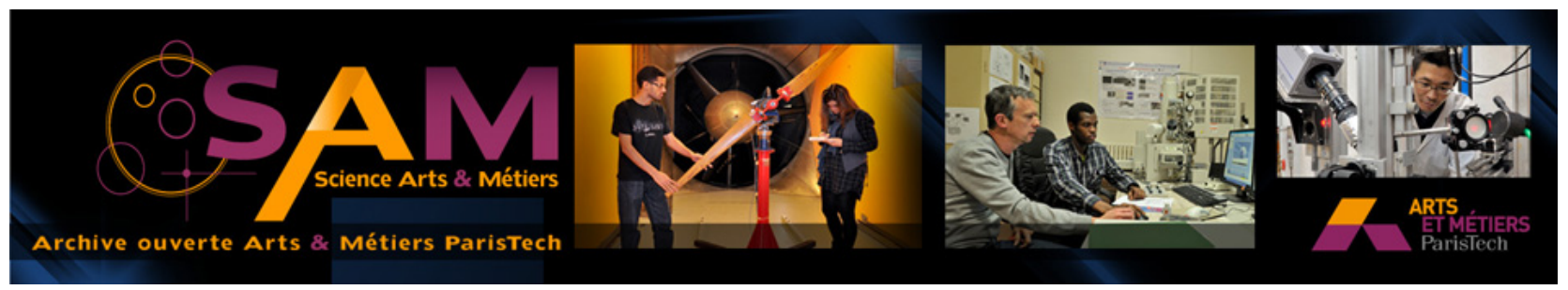

Science Arts \& Métiers (SAM)

is an open access repository that collects the work of Arts et Métiers ParisTech researchers and makes it freely available over the web where possible.

This is an author-deposited version published in: http://sam.ensam.eu

Handle ID: .http://hdl.handle.net/10985/9860

\section{To cite this version :}

José OUTEIRO, Pierrick LENOIR, A. BOSSELUT - Thermo-mechanical effects in drilling using metal working fluids and cryogenic cooling and their impact in tool performance - Production Engineering p.1-12 - 2015 


\title{
Thermo-mechanical effects in drilling using metal working fluids and cryogenic cooling and their impact in tool performance
}

\author{
J. C. Outeiro ${ }^{1} \cdot$ P. Lenoir $^{1} \cdot$ A. Bosselut ${ }^{2}$
}

\begin{abstract}
Cryogenic machining opens up new industrial perspectives in difficult-to-cut materials like nickel-based alloys. In particular, drilling is an operation that generates high thermal and mechanical loading to the drill. Therefore, tool performance, hole geometry and surface integrity can be highly affected. The objective of this study is to analyse tool performance during drilling of IN718 using conventional metal working fluids (MWF) and cryogenic cooling conditions, and correlate it with the thermo-mechanical phenomena. This study is conducted with standard coated cemented carbide twist drills, designed to work with MWF. The results show that drill performance under cryogenic cooling is strongly affected by its geometry. The axial force, drilling torque and tool wear/failure are higher under cryogenic cooling when compared to conventional MWF. Therefore, in order to take advantage of the cryogenic machining, new drill design is required, which currently is not available on the market.
\end{abstract}

Keywords Drilling · Metal working fluid · Cryogenic · Thermo-mechanical phenomena · Tool wear · Drilling simulation $\cdot$ Flow simulation

\footnotetext{
J. C. Outeiro

jose.outeiro@ensam.eu;

http://www.ensam.eu

1 Arts et Metiers ParisTech, LaBoMaP, Rue Porte de Paris, 71250 Cluny, France

2 MECACHROME, Rue de Saint Règle, ZI de la Boitardière, 37403 Amboise, France
}

\section{Introduction}

Current research in metal cutting are carried out to increase the efficiency of machining operations and the quality of machined parts while reducing the environmental impact of such operations. Cryogenic machining is a way to address that issue. This technology has shown for turning operation the possibility to decrease tool wear $[1,2]$ and increase compressive residual stresses in the machined part [3-5]. Moreover, it has the advantage to offer a clean and nontoxic process, because of the properties of liquid nitrogen $\left(\mathrm{LN}_{2}\right)$, mainly used in this kind of assistance. The $\mathrm{LN}_{2}$ evaporates in the atmosphere after contacting the cutting zone (it doesn't need reprocessing) and is safe for the operator (no skin or lung injuries).

Cryogenic machining opens up new industrial perspectives in machining difficult-to-cut materials such as nickel and titanium based alloys. These materials offer interesting properties such as high temperatures strength and good corrosion resistance, but those same characteristics become a barrier when these materials have to be machined. There are no studies available on the influence of cryogenic cooling in drilling difficult-to-cut alloys such as IN718 nickel-based alloy. This study is of great industrial importance, because the drilling operation generates greater thermo-mechanical loadings on the tool and on the workpiece when compared to external machining (turning, milling). Therefore, tool life, hole geometry and surface integrity are greatly affected.

All studies on cryogenic machining performed up to now have used existing (standard) commercial cutting tools, developed to work with common metal working fluids (MWF) or near dry conditions. These studies have shown a large scatter in tool wear (thus tool life), which can be partially attributed to the subpar performance of the existing cutting tools under cryogenic temperatures. 
Moreover, most of these studies compare the performance of cryogenic machining with dry or near dry conditions [3], which is not the case in most industrial applications.

The objective of the present study is to analyse tool wear (thus tool life) generated by drilling of IN718 under cryogenic cooling conditions, using standard coated cemented carbide twist drills (designed to work with high pressure MWF), and compare it to tool wear generated by drilling under MWF (present industrial reference). Thermo-mechanical phenomena generated during drilling will be analysed and used to explain the differences in tool performance observed between cryogenic cooling (hereinafter referred to as $\mathrm{LN}_{2}$ cooling) and MWF conditions.

\section{Experimental and numerical procedures}

\subsection{Experimental set-up and parameters}

Drilling tests were performed in two three-axes CNC milling machines: one MAZAC FH-580-40 (dedicated to the cryogenic machining) and one DMG model DMU 65V (used for both cryogenic machining and MWF), both equipped with a designed experimental set-up for forces/torque and temperature measurements. These tests were performed on nickel-based alloy work material, Inconel 718 (hereinafter referred to as IN718, solution-treated and agehardened, having a hardness equal to 44 HRC), using standard coated cemented carbide (TiAlN coating) twist drills. It is worth pointing out that these drills are designed to work with high pressure MWF, delivered to the cutting zone using the cooling channels in the drill (see Fig. 1).

Drill geometry was inspected according to the ISO 3002-1/2 and DIN 1414-1/2 standards, as described by

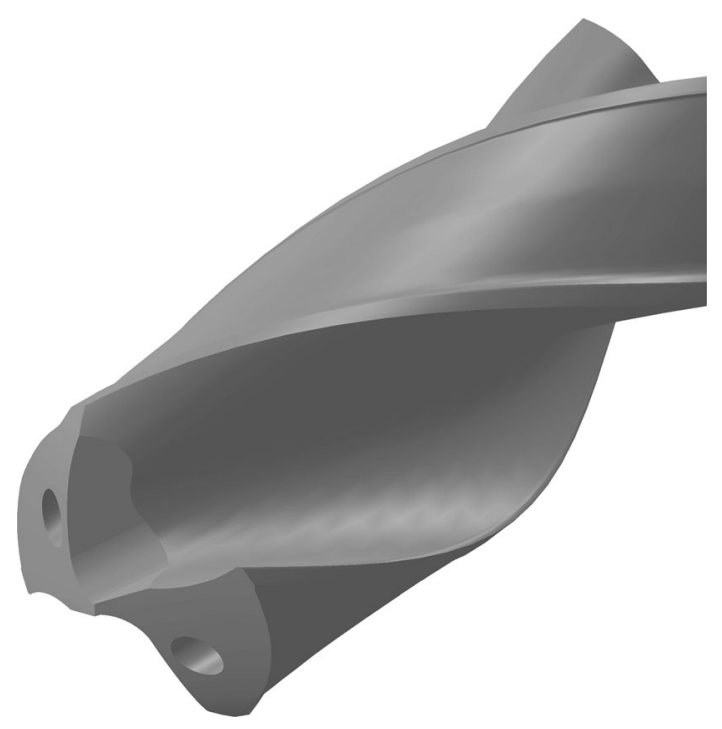

Fig. 1 Twist drill
Astakhov [6], using both ZOLLER (models Genius3 and 3DCheck) and ALICONA (model InfiniteFocus) equipments. These equipments permitted to scan the tool geometry, which was used for tool inspection and to generate the drill CAD model for the numerical simulations (see Fig. 1). The tool inspection permitted to measure the following drill geometric parameters: drill diameter of $12.015 \mathrm{~mm}$, back taper of $0.09^{\circ}$, helix angle of $30^{\circ}$, (four) margins width of $0.837 \mathrm{~mm}$, point angle of $143.4^{\circ}$, drill runout of $0.007 \mathrm{~mm}$, chisel edge angle of $56.7^{\circ}$, chisel edge length of $0.397 \mathrm{~mm}$, chisel edge centrality of $0.013 \mathrm{~mm}$, web thickness of $0.173 \mathrm{~mm}$, gash face angle of $64^{\circ}$, gash radius of $1.420 \mathrm{~mm}$, normal rake angle varying from $-10^{\circ}$ to $32^{\circ}$, clearance angle varying from $10^{\circ}$ to $18^{\circ}$ and an average edge radius of $55 \mu \mathrm{m}$. Figure 2 shows the variation of the rake/clearance angles and cutting edge radius in the function of the distance from the drill center.

The drilling tests were performed varying the cutting speed $\left(v_{c}\right)$, feed $(f)$ and type of coolant (MWF and $\mathrm{LN}_{2}$ ). The values of these parameters were identified based on the toolmaker recommendation and after performing preliminary drilling tests under wide range of drilling conditions. Table 1 shows the cutting and cooling conditions used in the experimental drilling tests.

The MWF was composed by $95 \%$ of water and $5 \%$ of a synthetic cutting fluid (supplied by TOTAL, commercial designation VULSOL $5000 \mathrm{~S}$ ) at 20 bar pressure. As far as cryogenic cooling is concerned, $\mathrm{LN}_{2}$ at 10 bar pressure was delivered to the cutting zone. Special designed cryogenic equipment developed by MECACHROME company was used to deliver the $\mathrm{LN}_{2}$ to the drill bit. This equipment was composed by a $\mathrm{LN}_{2}$ reservoir, 20 bar pump, rotary union, phase separator and insulated pipe.

During the drill tests axial force and drilling torque were measured using two piezoelectric dynamometers from KISTLER, models 9123C and 9273. Several drills were instrumented with thermocouples type $\mathrm{K}$ of $0.25 \mathrm{~mm}$ diameter. In order to measure the temperatures as closest as possible of the cutting edge but at different locations, the thermocouples were placed at $1 \mathrm{~mm}$ from this edge and at two locations: $0.74 \mathrm{~mm}$ (temperature $\mathrm{T}_{1}$ ) and $3.54 \mathrm{~mm}$ (temperature $\mathrm{T}_{2}$ ) from the drill margins (Fig. 3). During the temperature measurement tests the drill was kept static and fixed to the CNC milling machine table, while the workpiece was rotating and attached to the spindle using a designed fixation system, as shown in Fig. 4. Special attention was paid in centering the tool in relation to spindle axis in order to minimize runout errors.

\subsection{Numerical models and parameters}

In order to understand the thermal phenomena occurring during drilling under MWF and $\mathrm{LN}_{2}$ cooling conditions, 

rake/clearance angles and cutting edge radius of the drill in function of the distance from the drill center
Fig. 2 Variation of the
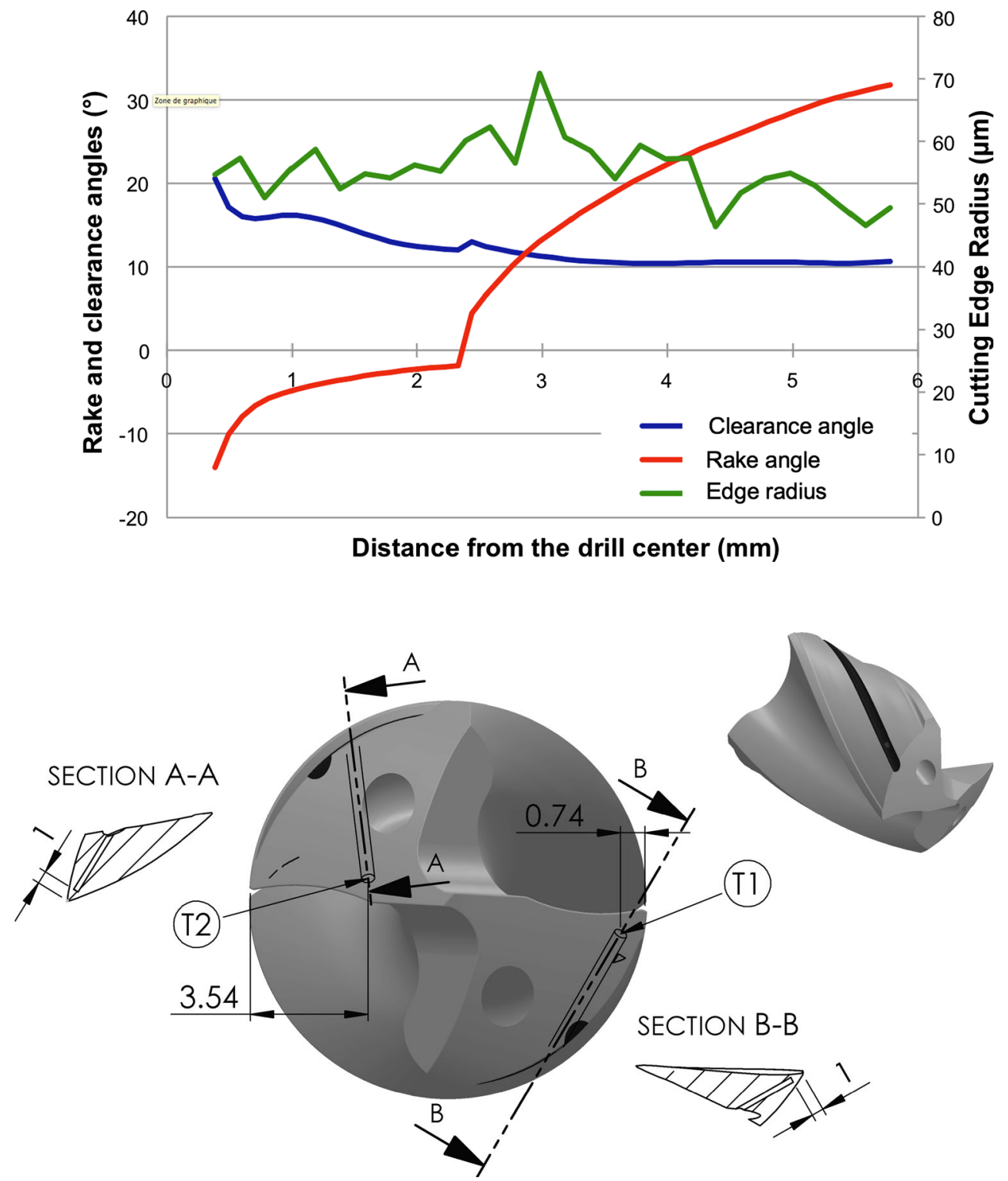

Fig. 3 Drill instrumentation with thermocouples type $\mathrm{K}$ for temperature measurements. $T_{l}$ and $T_{2}$ show the location of the thermocouples

Table 1 Cutting parameters and coolant conditions the commercial FEA software DEFORM-3D version 11, a Lagrangian implicit code, was used to simulate the threedimensional cutting process of IN718 alloy. A finite element model was developed for the drilling operation, and this was consisted of the workpiece and tool, as shown in Fig. 5. The simulation was started with the tool cutting edges fully engaged in the workpiece to decrease the simulation time. A coupled transient thermo-mechanical analysis (corresponding to the chip formation and with a duration of $0.15 \mathrm{~s}$ ) was performed, followed by a steadystate thermal analysis to predict the tool temperature for longer drilling time.

The workpiece was modeled as thermo-viscoplastic and the tool as elastic. They were meshed using 60,000 and 200,000 tetrahedral elements, respectively. To model the thermo-viscoplastic behaviour of IN718 alloy, the Johnson-Cook constitutive model was employed [7], which is represented by the following equation: 


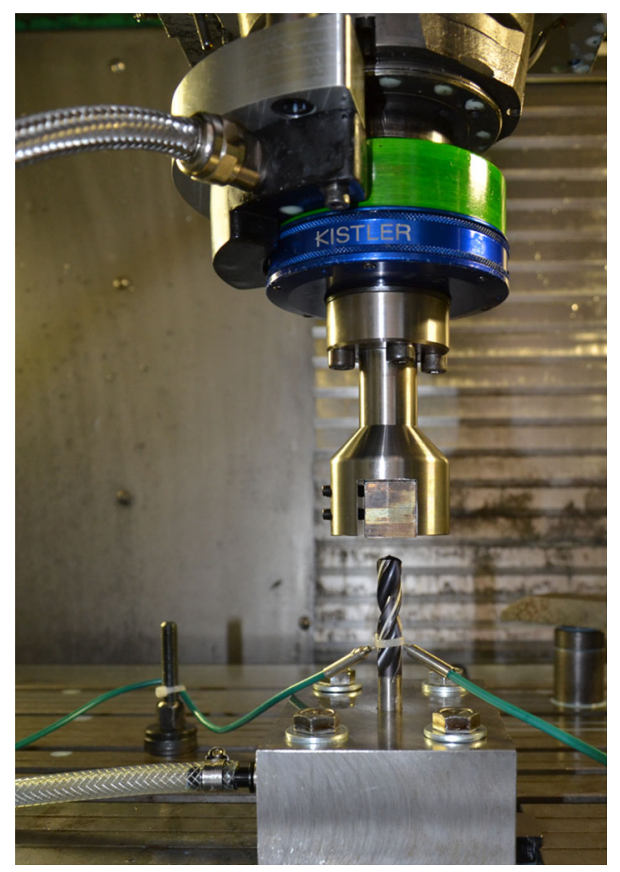

Fig. 4 Experimental set-up for temperature measurement

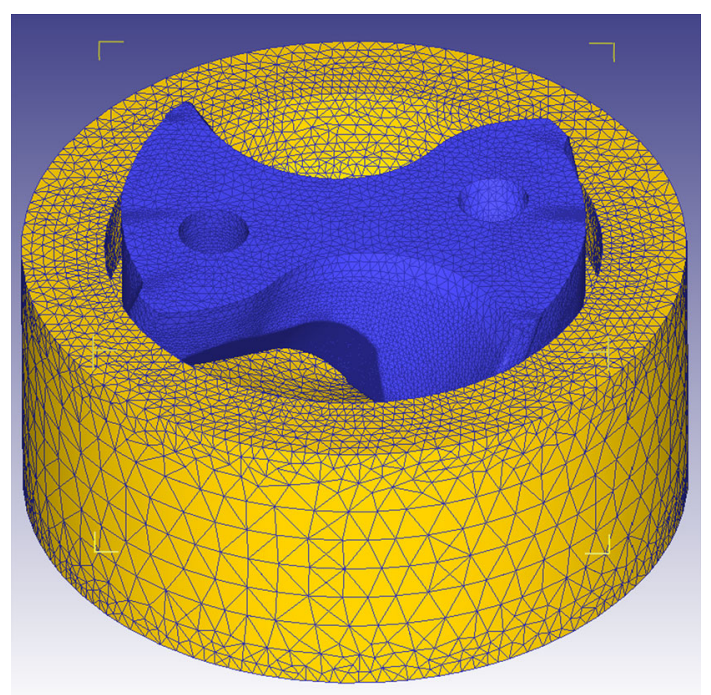

Fig. 5 Drilling operation model, meshed with 60,000 (workpiece) and 200,000 (tool) tetrahedral elements

$\bar{\sigma}=\underbrace{\left(A+B \overrightarrow{\bar{\varepsilon}}^{n}\right)}_{\text {Strain hardening effect }} \underbrace{\left[1+C \ln \left(\frac{\dot{\bar{\varepsilon}}}{\overline{\dot{\bar{\varepsilon}}}}\right)\right]}_{\text {Strain-rate (viscosity) effect }} \underbrace{\left[1-\left(\frac{T-T_{\text {room }}}{T_{m}-T_{\text {room }}}\right)^{m}\right]}_{\text {Thermal softening effect }}$

where $\bar{\sigma}$ is the equivalent stress (MPa), $\bar{\varepsilon}$ is the equivalent plastic strain, $\dot{\bar{\varepsilon}}$ is the equivalent plastic strain rate $\left(\mathrm{s}^{-1}\right), \dot{\bar{\varepsilon}}_{0}$ is the reference equivalent plastic strain rate $\left(0.001 \mathrm{~s}^{-1}\right)$, $T$ is the temperature $\left({ }^{\circ} \mathrm{C}\right), T_{m}$ is the melting temperature of the work material $\left(1500{ }^{\circ} \mathrm{C}\right)$ and $T_{\text {room }}$ is the room temperature $\left(-200^{\circ} \mathrm{C}\right) . A, B, C, n$ and $m$ are material coefficients, which were obtained from experimental quasistatic and dynamic compression tests using a Gleeble machine at different strain-rates and temperatures, including negative temperatures. A detailed description of the experimental set-up and procedure is provided in [8]. They are equal to $605 \mathrm{MPa}, 1280 \mathrm{MPa}, 0.0117,0.139$ and 3.98, respectively. The elastic and thermal properties of the IN718 and of the drill are given in Deform software database.

Concerning the tribological characteristics of the toolchip and tool-workpiece interfaces, the Zorev's model was employed [9]. The value of the friction coefficient was determined from tribological tests described in $[10,11]$. These tests permitted to determine the apparent friction coefficient $\left(\mu_{\text {app }}\right)$, which includes both contributions of interfacial (local) adhesive phenomena $\left(\mu_{a d h}\right)$ and macroscopic plastic deformation $\left(\mu_{\text {plast }}\right)$. For the numerical simulation, $\mu_{\text {adh }}$ should be used, which for the range of sliding velocities and contact pressures applied in the machining tests, this coefficient can be represented as a function of the sliding velocity $\left(v_{s}\right)$, represented by the following equation:

$\mu_{\text {adh }}=c_{1} \times v_{s}+c_{2}$

where the coefficients $c_{i}(\mathrm{i}=1,2)$ are equal to -0.004 and 0.406 , for $\mathrm{LN}_{2}$ cooling, and equal to $-0.004,0.340$ for MWF. Concerning the limit shear stress $\left(\tau_{\text {limit }}\right)$, this is equal to the yield shear stress $\left(\tau_{y}\right)$ and was calculated based on the yield stress $\left(\sigma_{y}\right)$ and the von Mises criterion.

The determination of the heat exchange with coolant is very critical for an accurate prediction of the temperature distributions in the tool and workpiece. This heat exchange was modeled by defining a convection heat transfer coefficient $\left(h_{f}\right)$ and temperature $\left(T_{f}\right)$ of the coolant. The determination of $h_{\text {cryogenic }}$ is particularly difficult, because this coefficient depends on several factors [12]. For such reason, several values of $h_{\text {cryogenic }}$ can be found in the literature, varying from 2 to $50 \mathrm{~kW} /\left(\mathrm{m}^{2} \mathrm{~K}\right)[13,14]$. These values were estimated based on experimental tests or heat transfer calculations. Astakhov [15] proposed the following equation to estimate $h_{f}$ in metal cutting:

$h_{f}=\frac{0.20}{b^{0.35} \times g^{0.33}} \cdot \frac{v_{f}^{0.65} \times k_{f}^{0.67} \times c_{p-f}^{0.33} \times \gamma_{f}^{0.33}}{v_{f}^{0.32}}$

where $b$ is the equivalent length $(m), g$ is the acceleration due to gravity $\left(\mathrm{m}^{2} / \mathrm{s}\right)$, and the remaining parameters are properties of the fluid, namely: $v_{f}$ is the velocity $(\mathrm{m} / \mathrm{s}), k_{f}$ is the thermal conductivity $(\mathrm{W} / \mathrm{m} \mathrm{K}), \gamma_{f}$ is the specific weight $\left(\mathrm{kg} / \mathrm{m}^{3}\right), v_{f}$ is the dynamic viscosity (Pa s) and $c_{p}$ is the specific heat capacity (J/kg K). Based on Eq. (3), an $h_{\text {cryogenic }}$ of $6270 \mathrm{~W} /\left(\mathrm{m}^{2} \mathrm{~K}\right)$ was obtained for $\mathrm{LN}_{2}$ and 
$h_{M W F}$ of $930 \mathrm{~W} /\left(\mathrm{m}^{2} \mathrm{~K}\right)$ was obtained for MWF. Based on the experimental measurements, an initial temperature was applied to the drill, being this temperature equal to $20{ }^{\circ} \mathrm{C}$ for MWF and $-170{ }^{\circ} \mathrm{C}$ for $\mathrm{LN}_{2}$ cooling.

In order to understand how tool geometry (including the diameter and location of the coolant channels on the flank face) influences the efficiency of the cooling process, fluid mechanics simulations were performed. The Reynolds average Navier-Stokes (RANS) and Lagrangian equations were used to simulate $\mathrm{LN}_{2}$ flows in drilling operation by integrating the standard SST k- $\omega$ turbulence model [16]. Three-dimensional steady flow model of the incompressible fluids $\left(\mathrm{LN}_{2}\right)$ was developed using STAR CCM+ commercial software. Figure 6 shows the model of the drilling operation, composed by three parts: drill, workpiece and fluid. This model was meshed with about 400,000 polyhedron cells for the drill, 450,000 cells for the fluid and 240,000 cells for the workpiece. Small mesh size was applied in the critical regions where strong gradients can occur, as well as at parts surface. In the last case, prism layer mesh is used to increase the accuracy of the fluidsolid (wall) interaction. In this model, the workpiece was considered static while the tool was rotating at a given rotation speed, calculated from the selected cutting speed

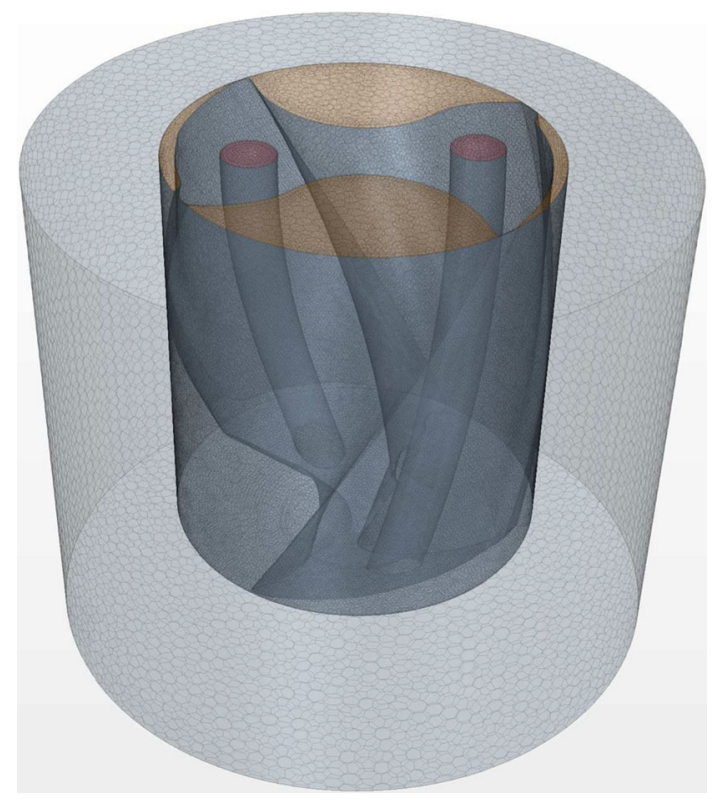

Fig. 6 Fluid mechanics model of the drilling operation, meshed with about 400,000 polyhedron cells for the drill, 450,000 cells for the fluid and 240,000 cells for the workpiece presented in Table 1. Since STAR CCM+ software cannot simulate rotation with deforming mesh, the solution was to consider the rotation with a moving reference frame (MRF) model. Table 2 shows the physical and thermal properties of the $\mathrm{LN}_{2}$, while Table 3 shows the coefficients of the SST $\mathrm{k}-\omega$ turbulence model, all data obtained from the literature $[12,17]$.

Concerning to the boundary conditions, an inlet pressure of 8 bar and an inlet fluid temperature of $-196{ }^{\circ} \mathrm{C}\left(\mathrm{LN}_{2}\right.$ boiling temperature) were applied. The inlet pressure was calculated based on the pressure loss in the piping. Outlet conditions were taken as ambient pressure of 1 bar (absolute pressure) and temperature of $20^{\circ} \mathrm{C}$.

\section{Results}

\subsection{Tool performance}

Tool performance was evaluated by performing tool wear tests under MWF and $\mathrm{LN}_{2}$ cooling conditions. Two tool wear curves of VB in function of the drilling depth were obtained at the optimal cutting conditions for each cooling strategy. These optimal cutting conditions were determined applying the concept of minimal specific cutting energy, according to the NF E66-520 standard. The corresponding optimal cutting speed and feed are the following: (1) $v_{c}=10 \mathrm{~m} / \mathrm{min}$ and $f=0.11 \mathrm{~mm}$, for $\mathrm{LN}_{2}(p=10 \mathrm{bar})$; (2), $v_{c}=24 \mathrm{~m} / \mathrm{min}$ and $f=0.11 \mathrm{~mm}$, for $\mathrm{MWF}$ $(p=20$ bar). Figure 7 shows these two tool wear curves and some images of the tool at the end of the tests. This figure clearly shows, for this particular drill geometry/material, that lower tool life is obtained when drilling under $\mathrm{LN}_{2}$ cooling (9 $\mathrm{min}, 240 \mathrm{~mm}$ drilling depth), when compared to the tool life obtained under MWF conditions (21 min, $1450 \mathrm{~mm}$ drilling depth). However, as shown in Fig. 7, cutting edge (for $\mathrm{LN}_{2}$ ) and periphery corner (for MWF) chipping occurred before VB reached the limit of $0.3 \mathrm{~mm}$. Tool images of the flank face and margins show strong tool wear and fracture under $\mathrm{LN}_{2}$ cooling. In particular, multiple fractures are visible at the

Table 3 Coefficients of the SST k- $\omega$ turbulence model [17]

\begin{tabular}{lllllllll}
\hline Fluid & $\sigma_{\mathrm{k} 1}$ & $\sigma_{\omega 1}$ & $\beta_{1}$ & $\sigma_{\mathrm{k} 2}$ & $\sigma_{\omega 2}$ & $\beta_{2}$ & $\alpha$ & $\beta$ \\
\hline $\mathrm{LN}_{2}$ & 0.85 & 0.5 & 0.075 & 1.0 & 0.856 & 0.0828 & 1 & 0.09 \\
\hline
\end{tabular}

Table 2 Physical and thermal properties of the fluids [12]

\begin{tabular}{lllllll}
\hline Fluid & $\begin{array}{l}\text { Boiling } \\
\text { point }(\mathrm{K})\end{array}$ & $\begin{array}{l}\text { Density } \\
\left(\mathrm{kg} / \mathrm{m}^{3}\right)\end{array}$ & $\begin{array}{l}\text { Specific heat } \\
(\mathrm{J} / \mathrm{kg} \mathrm{K})\end{array}$ & $\begin{array}{l}\text { Dynamic } \\
\text { viscosity }(\mathrm{mPa} \mathrm{s})\end{array}$ & $\begin{array}{l}\text { Thermal } \\
\text { conductivity }(\mathrm{W} / \mathrm{m} \mathrm{K})\end{array}$ & $\begin{array}{l}\text { Convection } \\
\text { coefficient }\left(\mathrm{W} /\left(\mathrm{m}^{2} \mathrm{~K}\right)\right.\end{array}$ \\
\hline $\mathrm{LN}_{2}$ & 77.36 & 807.3 & 2050 & 0.158 & 0.1396 & 6270 \\
\hline
\end{tabular}


Fig. 7 Tool wear (VB) in function of the drilling depth, using $\mathrm{LN}_{2}\left(v_{c}=10 \mathrm{~m} / \mathrm{min}\right.$, $\operatorname{MWF}\left(v_{c}=24 \mathrm{~m} / \mathrm{min}\right.$, $f=0.11 \mathrm{~mm}, p=20 \mathrm{bar})$ $f=0.11 \mathrm{~mm}, p=10 \mathrm{bar})$ and

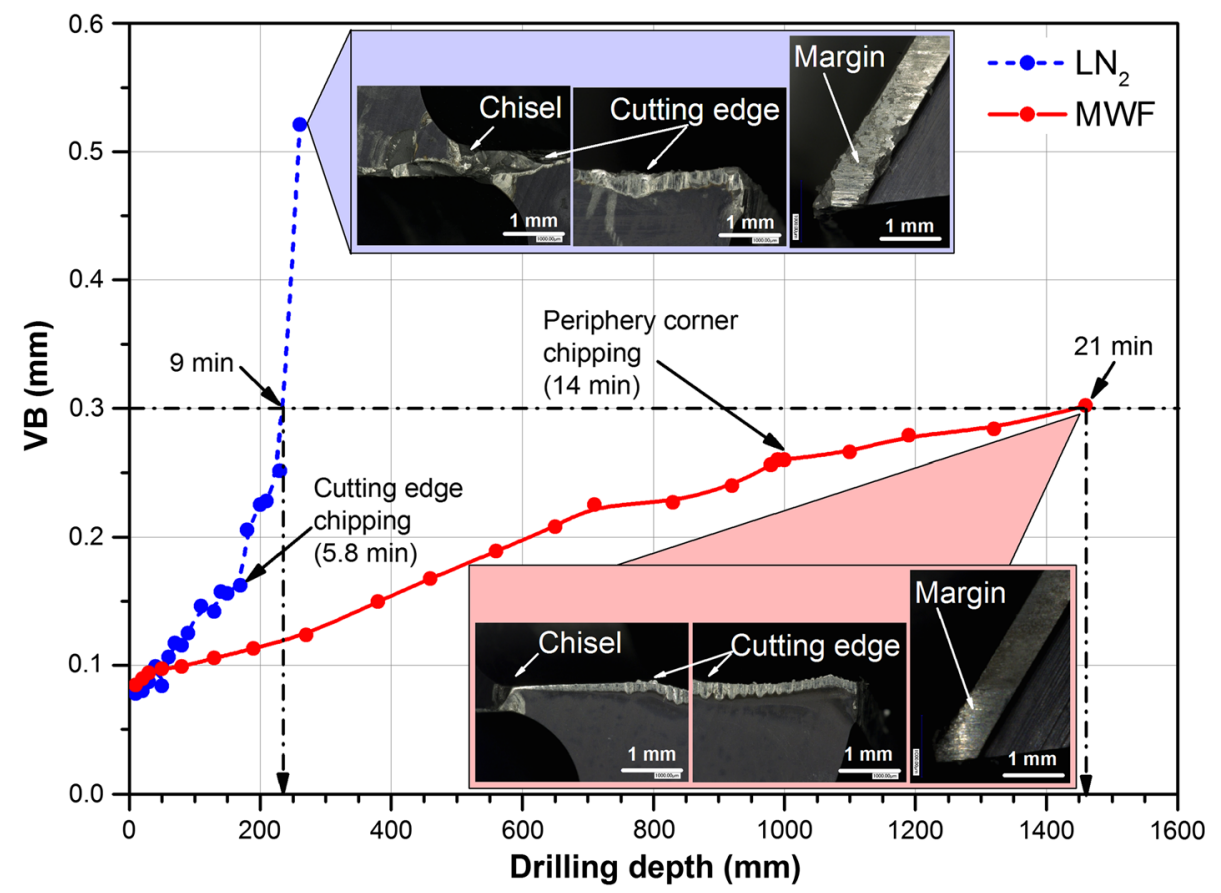

Fig. 8 Tool margins wear at the end of the tool wear tests, using $\mathrm{LN}_{2}\left(\mathrm{v}_{\mathrm{c}}=10 \mathrm{~m} / \mathrm{min}\right.$, $\mathrm{f}=0.11 \mathrm{~mm}, p=10 \mathrm{bar}$ ) and $\operatorname{MWF}\left(\mathrm{v}_{\mathrm{c}}=24 \mathrm{~m} / \mathrm{min}\right.$, $\mathrm{f}=0.11 \mathrm{~mm}, p=20 \mathrm{bar}$ )
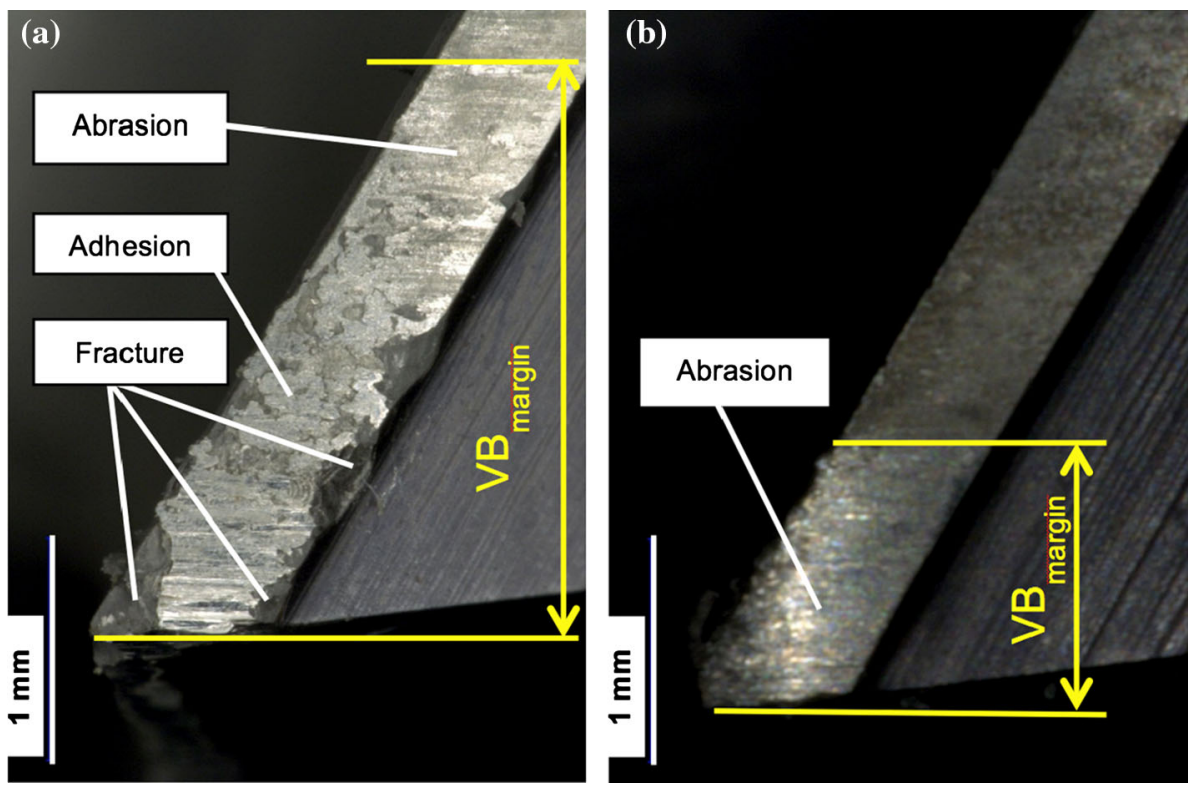

tool margins, as well as at the cutting and chisel edges. These multiple fractures may are a consequence of the embrittlement of the carbide substrate under very negative temperatures.

Figure 8 shows in detail the principal wear modes at the tool margins, which include both abrasive and adhesive modes, combined with multiple fractures. Moreover, VB at the tool margins under $\mathrm{LN}_{2}$ cooling is more than twice than the corresponding VB under MWF. In order to understand the causes of this reduction of tool life under $\mathrm{LN}_{2}$ cooling, mechanical (axial force and drilling torque) and thermal phenomena (tool temperatures) were investigated, described as follows.

\subsection{Axial force and drilling torque}

Both axial force $\left(\mathrm{F}_{\mathrm{a}}\right)$ and drilling torque $\left(\mathrm{M}_{\mathrm{d}}\right)$ were measured during the drilling operation. Figures 9 and 10 show for both MWF and $\mathrm{LN}_{2}$, the axial force and the torque generated in drilling IN718, applying the cutting speed and feed presented in these figures. For these conditions, the axial force is almost constant during the drilling process, 

using $\operatorname{MWF}\left(v_{c}=24 \mathrm{~m} / \mathrm{min}\right.$, $f=0.11 \mathrm{~mm} / \mathrm{rev}, p=20 \mathrm{bar}$ ) and $\mathrm{LN}_{2}\left(v_{c}=24 \mathrm{~m} / \mathrm{min}\right.$, $f=0.11 \mathrm{~mm} / \mathrm{rev}, p=10 \mathrm{bar}$ )
Fig. 9 Axial force generated

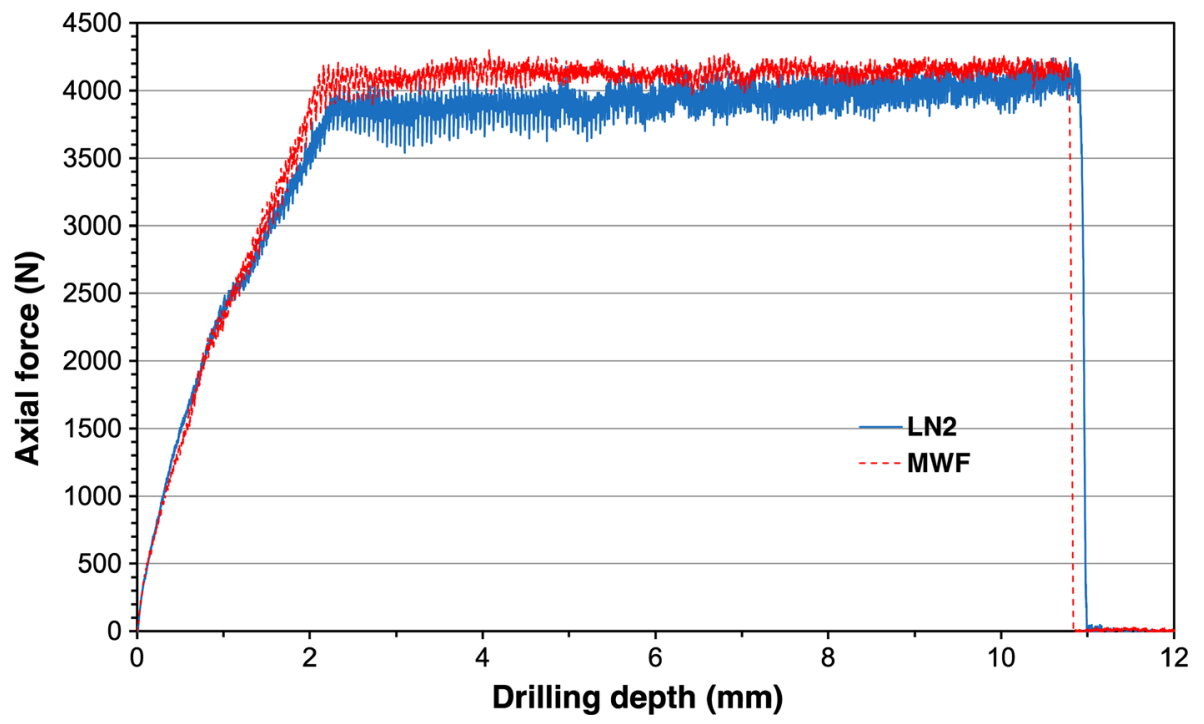

Fig. 10 Drilling torque generated using MWF $\left(v_{c}=24 \mathrm{~m} / \mathrm{min}\right.$, $f=0.11 \mathrm{~mm} / \mathrm{rev}, p=20 \mathrm{bar})$ and $\mathrm{LN}_{2}\left(v_{c}=24 \mathrm{~m} / \mathrm{min}\right.$, $f=0.11 \mathrm{~mm} / \mathrm{rev}, p=10 \mathrm{bar})$

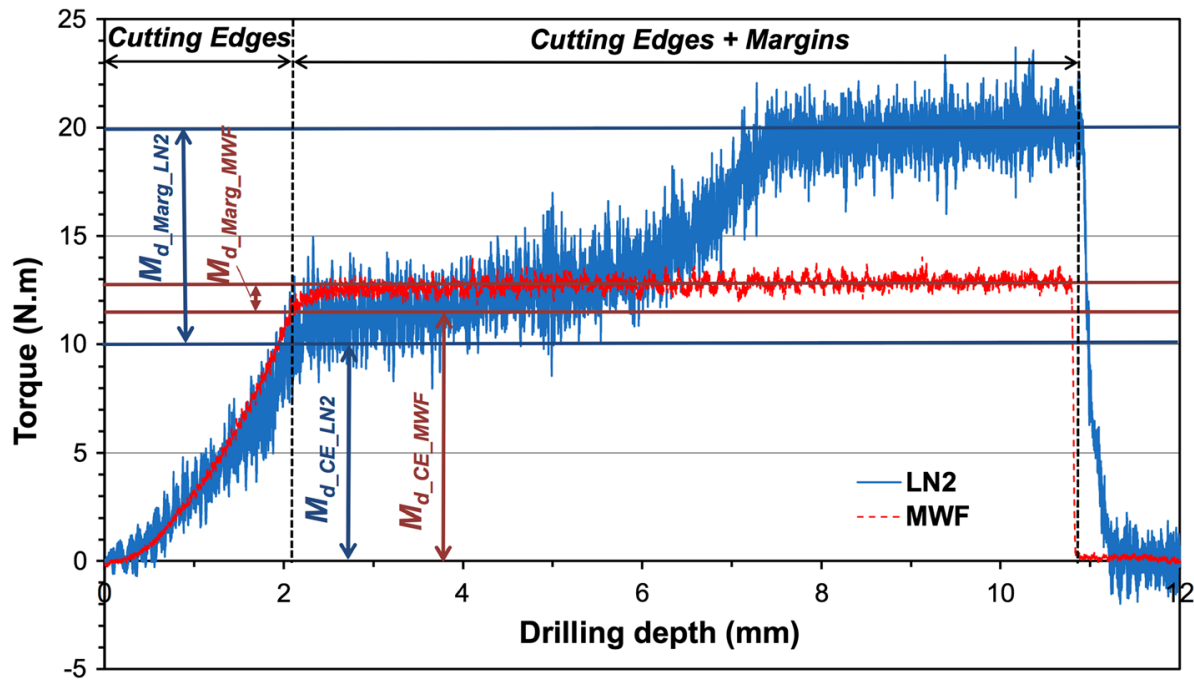

being slightly inferior when $\mathrm{LN}_{2}$ is applied (average values around $4000 \mathrm{~N}$ for the $\mathrm{LN}_{2}$ and $4150 \mathrm{~N}$ for the MWF). However, for this very short drilling time (between 10 and 23 s depending on the cutting conditions), the opposite was also observed (see Table 4).

As far as the torque is concerned, the results are different. Applying MWF, the torque is almost constant (average value around $13 \mathrm{~N} \mathrm{~m}$ ) during the drilling operation. However, applying $\mathrm{LN}_{2}$, the torque is initially slightly inferior to the MWF case, but it increases considerably (almost $45 \%$, from 11 to $20 \mathrm{~N} \mathrm{~m}$ ) for a drilling depth greater than $40 \%$ of the drilling diameter. Since the drilling torque results from the contribution of the cutting edges $\left(M_{d_{-} C E_{-} M W F}\right.$ and $\left.M_{d_{-} C E_{-} L N 2}\right)$ and the drill margins $\left(M_{d_{-} M a r g \_M W F}\right.$ and $\left.M_{d_{-} \text {Marg_LN2 }}\right)$, Fig. 10 shows that about $50 \%$ of the total drilling torque is generated at the drill margins for the $\mathrm{LN}_{2}$ case, when compared to only about
$11 \%$ for the MWF case. This increase in drilling torque at drill margins means that friction forces also increase and consequently drill margins wear. As it will be discussed later, these strong friction conditions at the tool margins are mainly caused by the insufficient back taper of the drill for cryogenic cooling conditions. The increase of the torque during drilling using $\mathrm{LN}_{2}$ reduces with the decrease of the cutting speed and feed.

Figure 11 shows the evolution of both axial force $\left(\mathrm{F}_{\mathrm{a}}\right)$ and drilling torque $\left(\mathrm{M}_{\mathrm{d}}\right)$ in function of drill wear VB. As shown in this figure, both axial force and torque increase with $\mathrm{VB}$, being higher when $\mathrm{LN}_{2}$ is used, when compared to MWF. Under $\mathrm{LN}_{2}$ cooling, the axial force is about $1000 \mathrm{~N}(25 \%)$ higher than the corresponding axial force under MWF conditions, and decreases as VB increases.

As far as the torque is concerned, it is about 3-4 $\mathrm{N} \mathrm{m}$ (23\%) higher than the corresponding torque under MWF 
Table 4 Predicted and measured results $\left(v_{c}=10 \mathrm{~m} / \mathrm{min}\right.$, $f=0.11 \mathrm{~mm})$

\begin{tabular}{llllll}
\hline Fluid & $\mathrm{F}_{\mathrm{a}}(\mathrm{N})$ & $\mathrm{M}_{\mathrm{d}}(\mathrm{Nm})$ & $\mathrm{T}_{\max }\left({ }^{\circ} \mathrm{C}\right)$ & $\mathrm{T}_{1}\left({ }^{\circ} \mathrm{C}\right)$ & $\mathrm{T}_{2}\left({ }^{\circ} \mathrm{C}\right)$ \\
\hline $\mathrm{LN}_{2}$-SIM & 3280 & 17 & 410 & -5 & -48 \\
$\mathrm{LN}_{2}$-EXP & $4110 \pm 83$ & $16 \pm 1$ & - & $-6 \pm 5$ & $-48 \pm 2$ \\
MWF-SIM & 3362 & 16 & 445 & 68 & 61 \\
MWF-EXP & $4050 \pm 110$ & $15 \pm 1$ & - & $32 \pm 6$ & $60 \pm 1$ \\
\hline
\end{tabular}

Fig. 11 Axial $\left(\mathrm{F}_{\mathrm{a}}\right)$ and drilling torque $\left(\mathrm{M}_{\mathrm{d}}\right)$ generated using $\operatorname{MWF}\left(v_{c}=24 \mathrm{~m} / \mathrm{min}\right.$, $f=0.11 \mathrm{~mm} / \mathrm{rev}, p=20 \mathrm{bar}$ ) and $\mathrm{LN}_{2}\left(v_{c}=10 \mathrm{~m} / \mathrm{min}\right.$, $f=0.11 \mathrm{~mm} / \mathrm{rev}, p=10 \mathrm{bar})$, in function of tool wear $V_{B}$

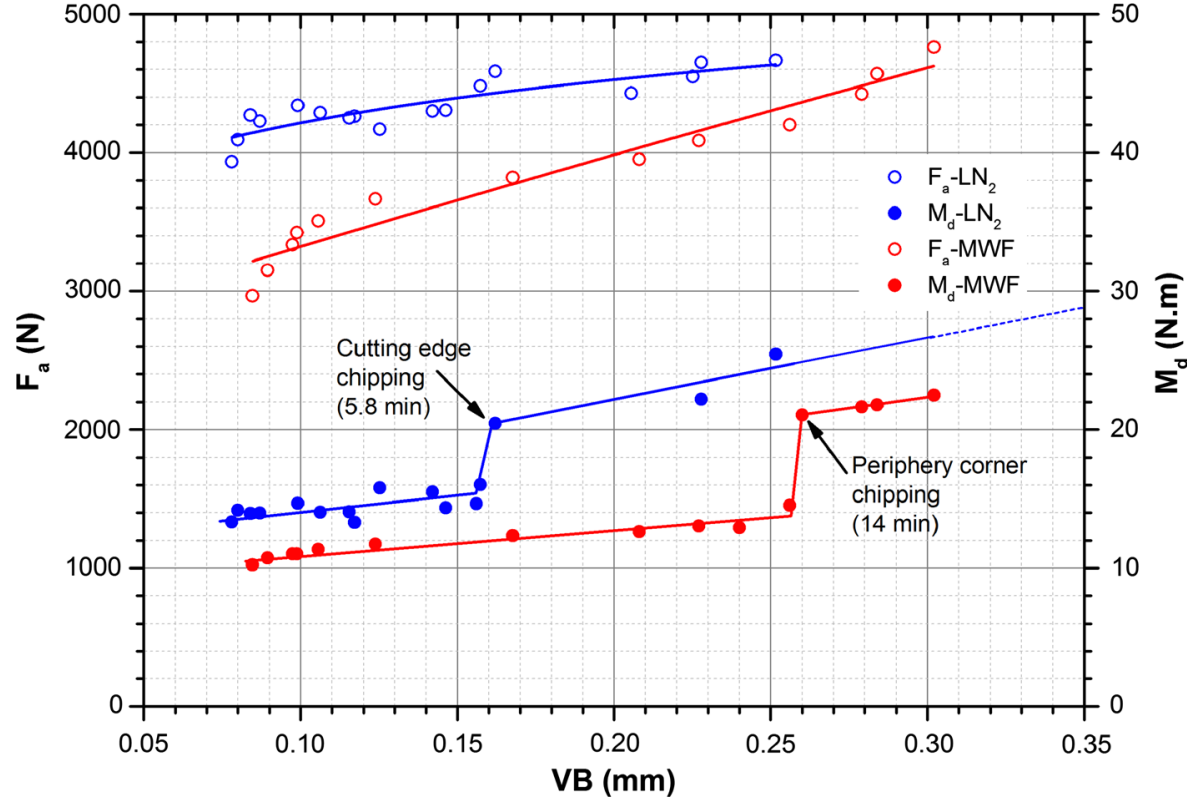

conditions. However, before tool wear VB reaches the limiting value $(0.3 \mathrm{~mm})$, drilling torque increases abruptly for both $\mathrm{LN}_{2}$ and MWF conditions. This increase occurs at $\mathrm{VB}$ of $0.16 \mathrm{~mm}$ for $\mathrm{LN}_{2}$ cooling and at $\mathrm{VB}$ of $0.26 \mathrm{~mm}$ for MWF. The reason for the torque jump was the cutting edge (for $\mathrm{LN}_{2}$ ) and periphery corner (for MWF) chipping. Apparently, the chipping did not produce also a jump in axial force, which can be justified by the fact that only approximately $30 \%$ of the axial force is generated by the cutting edges, when compared to $60 \%$ of the axial force generated by the chisel edge [6].

\subsection{Temperatures}

Figure 12 shows the temperatures at the two locations in the cutting tool (temperatures $T_{1}$ and $T_{2}$ in Fig. 3) in function of the cutting speed and feed, for both MWF and $\mathrm{LN}_{2}$ cooling conditions. These temperatures were obtained for a drilling depth of $10 \mathrm{~mm}$. Each cutting condition was repeated at least three times and the average values were calculated. The initial drill temperature was equal to $20{ }^{\circ} \mathrm{C}$ for MWF and $-170{ }^{\circ} \mathrm{C}$ for $\mathrm{LN}_{2}$ cooling.

Except for a cutting speed of $24 \mathrm{~m} / \mathrm{min}$, the temperatures at the two locations on the tool are lower when $\mathrm{LN}_{2}$ is applied, when compared to those obtained using
MWF. Using $\mathrm{LN}_{2}, \mathrm{~T}_{2}$ is negative, because the thermocouple is located closer to the cooling holes when compared to the other thermocouple $\left(\mathrm{T}_{1}\right)$ (see Fig. 3). Using a cutting speed of $24 \mathrm{~m} / \mathrm{min}$ results in an increase of the temperatures at these two locations, especially when $\mathrm{LN}_{2}$ is applied. Taking into account that for the same conditions higher drilling torque was measured for $\mathrm{LN}_{2}$ cooling, it seems to be obvious that higher temperatures will be also generated for those conditions. Temperature $T_{1}$ is higher when compared to temperature $T_{2}$, because: (1) the cutting speed depends on the considered point position at the cutting edge, being higher at the drill margins; (2) if $50 \%$ of the drilling torque is generated at the drill margins, high friction forces will be also generated at this zone. Therefore, high cutting speeds (thus high sliding velocity between the drill and the wall of the hole being drilled) combined with high friction forces, result in high thermal (friction) energy generated by unit of time. Moreover, taking into account that location $2\left(\mathrm{~T}_{2}\right)$ is closer to the cooling hole, higher temperatures will be obtained at the drill margins region (in this case temperature $T_{1}$ ). This region of high temperatures is visible on the tool flank face (Fig. 13), represented by a dark zone, which means that the reached temperatures were very high. 
Fig. 12 Temperature a $T_{1}$ and b $T_{2}$ in function of the cutting speed and feed, for both MWF (red barldark gray) and $\mathrm{LN}_{2}$ (blue bar/light gray) cooling conditions. Drilling depth equal to $10 \mathrm{~mm}$ (color figure online)
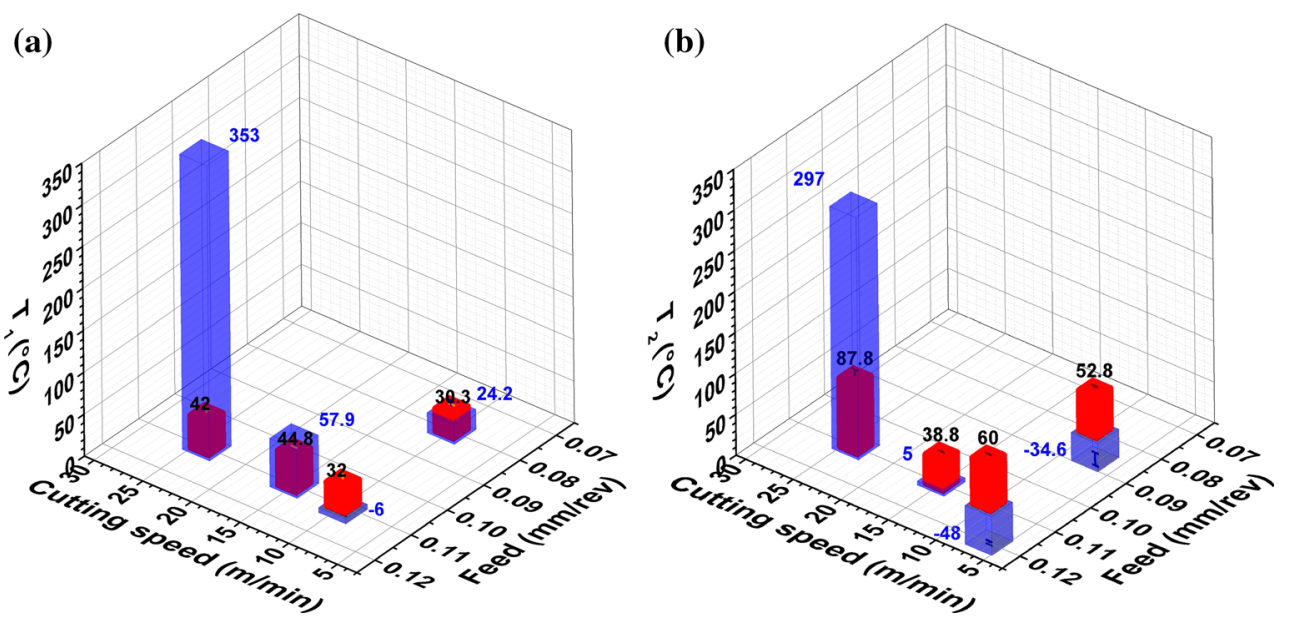

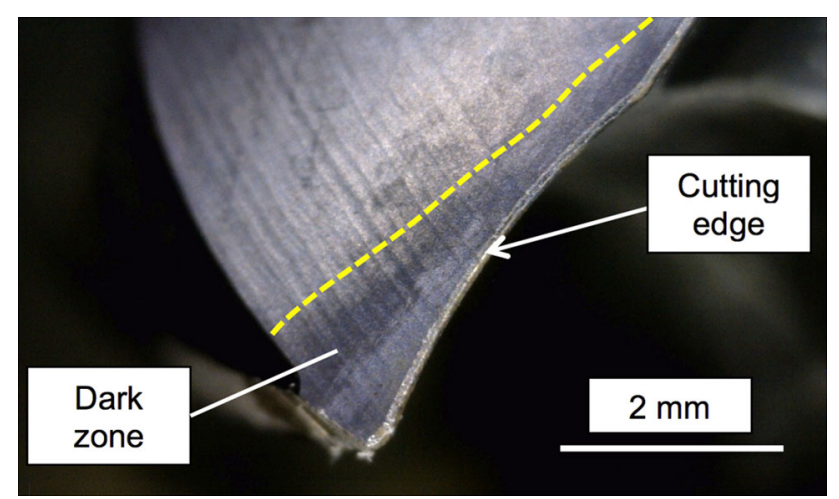

Fig. 13 Flank face of a drill used under $\mathrm{LN}_{2}$ cooling conditions $\left(v_{c}=10 \mathrm{~m} / \mathrm{min}, f=0.11 \mathrm{~mm} / \mathrm{rev}, \quad p=10 \mathrm{bar}\right.$, drilling depth $=$ $10 \mathrm{~mm})$

Table 5 Influence of thermal and springback effects on final hole diameter

\begin{tabular}{lllll}
\hline Fluid & $\Delta_{\mathrm{sb}}(\mathrm{mm})$ & $\Delta_{\mathrm{T}}(\mathrm{mm})$ & $\Delta_{\mathrm{c}}(\mathrm{mm})$ & $\mathrm{D}_{\mathrm{f}}(\mathrm{mm})$ \\
\hline MWF & -0.079 & -0.015 & -0.094 & 11.905 \\
$\mathrm{LN}_{2}$ & -0.089 & -0.028 & -0.117 & 11.883 \\
\hline
\end{tabular}

In order to determine the full drill temperature distribution, two numerical simulations were performed under the same cutting conditions $\left(v_{c}=10 \mathrm{~m} / \mathrm{min}\right.$, $f=0.11 \mathrm{~mm}$ ), one for $\mathrm{LN}_{2}$ cooling and another for MWF. The predicted and measured results are presented in Table 5 concerning to the axial force $\left(\mathrm{F}_{\mathrm{a}}\right)$, drilling torque $\left(\mathrm{M}_{\mathrm{d}}\right)$, maximum tool temperature $\left(\mathrm{T}_{\max }\right)$, and temperatures $\mathrm{T}_{1}$ and $\mathrm{T}_{2}$. In general, the predicted axial force is lower than that measured, while the drilling torque is almost identical. The higher measured axial force can be due to small changes of the chisel edge geometry of the real tool when compared to the CAD model that didn't changed.

As far as tool temperature is concerned, Figs. 14 and 15 show the predicted temperature distribution at the flank and rake faces, respectively. Figure $14 \mathrm{~b}$ shows that in a qualitative way, the shape of the predicted temperature distribution in the flank face is similar to the experimental shape shown in Fig. 13, which is a good indicator of the quality of the prediction. This is confirmed by the temperature measurements $T_{1}$ and $T_{2}$, where both predicted and measured temperatures in both locations 1 and 2 are identical (except for the MWF case at location 1). It is worth pointing out that the predicted temperatures $T_{1}$ and $\mathrm{T}_{2}$ were extracted from the model at the thermocouple locations, by averaging the nodal temperatures within a volume two times bigger than the bottom part of the thermocouple hole (about $0.2 \mathrm{~mm}^{3}$ ).

Comparing the predicted temperature distribution between $\mathrm{LN}_{2}$ cooling and MWF, Figs. 14 and 15 show also that the maximum tool temperature $\left(T_{\max }\right)$ is not significantly reduced when MWF is replaced by $\mathrm{LN}_{2}$. This temperature is $445^{\circ} \mathrm{C}$ for the MWF and $410{ }^{\circ} \mathrm{C}$ for the $\mathrm{LN}_{2}$ (see Table 5), representing a reduction of only about $8 \%$. The most important change when MWF is replaced by LN2 is the reduction of the tool region affected by high temperatures.

\section{Discussion}

Previous results have shown that tool performance under cryogenic cooling conditions was seriously compromised when compared to MWF coolant conditions. In order to understand the reasons for such weak performance under cryogenic cooling, the thermal and mechanical phenomena generated during drilling operations should be considered. Except for very short drilling time (as shown in Fig. 9), the results have shown that higher axial force and torque are generated when drilling under $\mathrm{LN}_{2}$ cooling (see Fig. 11). This is probably due to the increase of the work material resistance under very low (negative) temperatures. 
Fig. 14 Temperature distribution at the drill flank face in drilling using a MWF $\left(T_{\max }=445^{\circ} \mathrm{C}\right)$ and $\mathbf{b} \mathrm{LN}_{2}$ $\left(T_{\max }=410^{\circ} \mathrm{C}\right)$. $v_{c}=10 \mathrm{~m} / \mathrm{min}$, $f=0.11 \mathrm{~mm}$

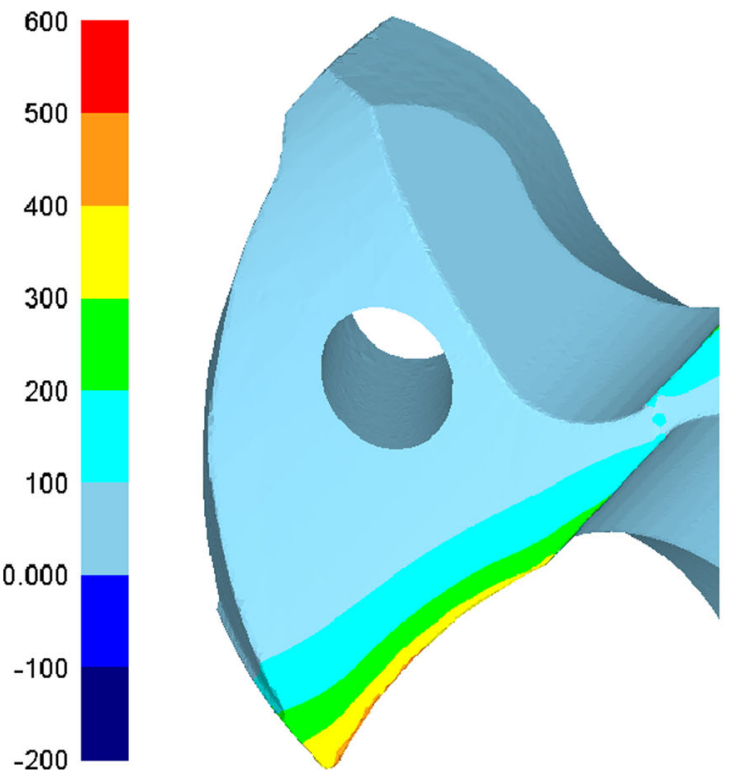

(a)

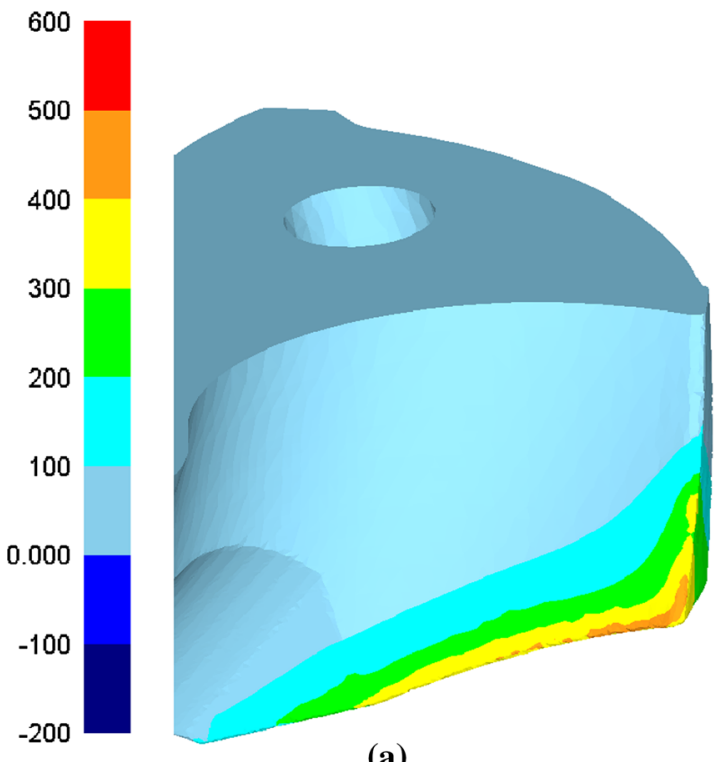

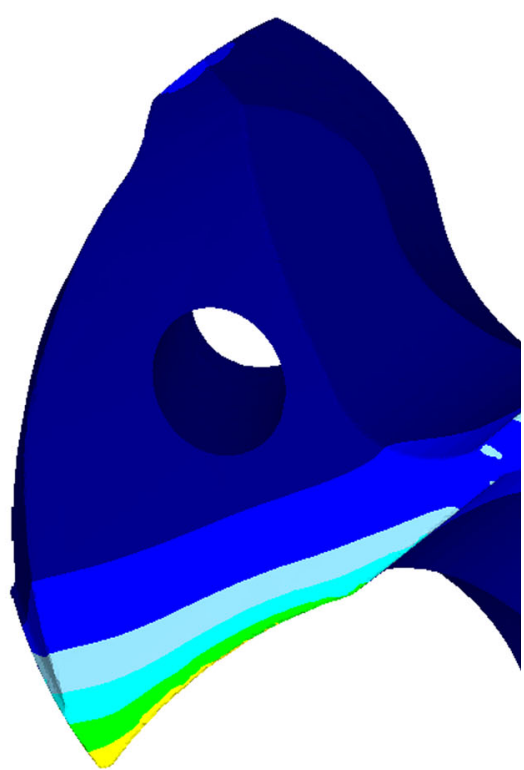

(b)

(b)
Fig. 15 Temperature distribution at the drill rake face in drilling using a MWF

$\left(T_{\max }=445^{\circ} \mathrm{C}\right)$ and $\mathbf{b} \mathrm{LN}_{2}$

$\left(T_{\max }=410^{\circ} \mathrm{C}\right)$.

$v_{c}=10 \mathrm{~m} / \mathrm{min}$,

$f=0.11 \mathrm{~mm}$ (a)

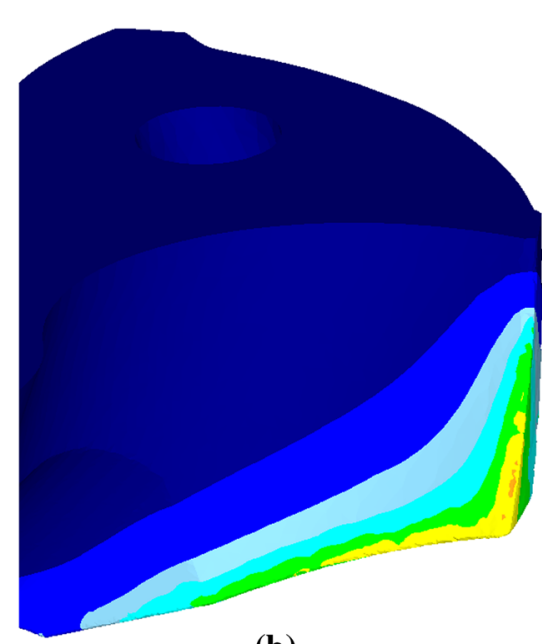

edge zone. The chisel edge is completely destroyed under $\mathrm{LN}_{2}$ cooling, while it is still visible under MWF coolant conditions. The highest axial force generated at the chisel edge under $\mathrm{LN}_{2}$ cooling is mainly responsible for this excessive tool wear and failure. This high axial force in drilling restricts the penetration rate of the drill, thus productivity. As the chisel edge is the major contributor of the axial force, one should: (1) reduce the length of this edge; and (2) improve the geometry of this edge, in particular under $\mathrm{LN}_{2}$ cooling conditions [6].

As far as the drilling torque is concerned, Fig. 10 shows that significant amount of the torque (up to $50 \%$ of the total drilling torque for the severest cutting condition used verify that the major tool wear/failure difference between the drills used under LN2 and MWF conditions is at chisel 
in the tests) can be generated at drill margins under $\mathrm{LN}_{2}$ cooling, when compared to MWF coolant conditions. This high drilling torque generated by drill margins means that high friction forces between these margins and wall of the hole being drilled will be generated. As a consequence, higher drill margins wear will be produced under $\mathrm{LN}_{2}$ cooling, when compared to MWF conditions (see Fig. 8). In order to understand the increase of the drilling torque at the drill margins when compared to MWF conditions, calculations of thermal (induced by the application of $\mathrm{LN}_{2}$ cooling) and springback effects on hole diameter were performed. Figure 16 shows schematically the procedure to estimate the final hole diameter based on these two effects. It is worth pointing out that the initial residual stress present in the work material before drilling was not considered in these calculations.

Table 5 shows the results obtained from such calculations when drilling under $\mathrm{LN}_{2}$ and MWF cooling conditions. The hole contraction $\left(\Delta_{c}\right)$ is higher under $\mathrm{LN}_{2}$ when compared to MWF, and therefore, a smaller final hole diameter $\left(D_{f}\right)$ is produced. This smaller hole diameter combined with lower lubrication capability of the LN2 when compared to the MWF, more intense friction forces between the wall of the hole being drilled and the drill margins will be generated, thus higher drilling torque.

In order to minimize the friction forces between the drill margins and the wall of the hole being drilled, higher back taper and reduced margins width should be used, in particular under $\mathrm{LN}_{2}$ cooling conditions.

The parameters associated to the $\mathrm{LN}_{2}$ and MWF cooling conditions, such as the flow-rate, pressure, temperature, application direction of the fluid jet, have an important function in the thermo-mechanical phenomena, thus in the tool performance. The flow-rate depends on the pressure and also on the diameter of the internal channels for fluid

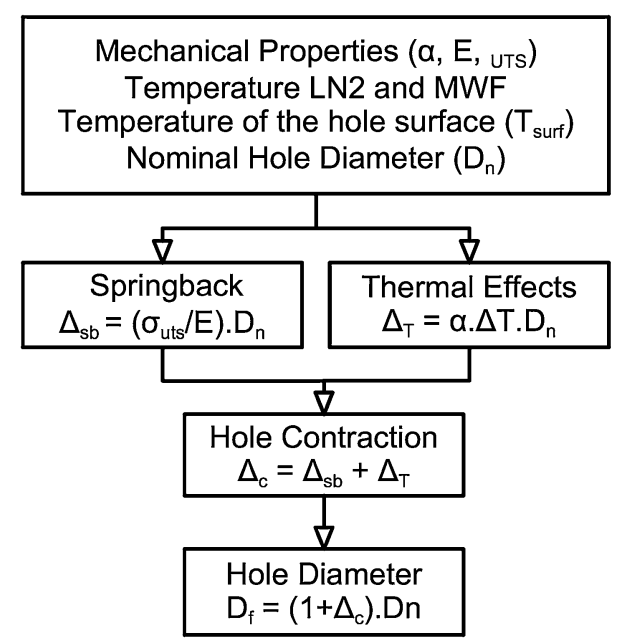

Fig. 16 Flow-chart of the thermal and springback effects on the hole diameter

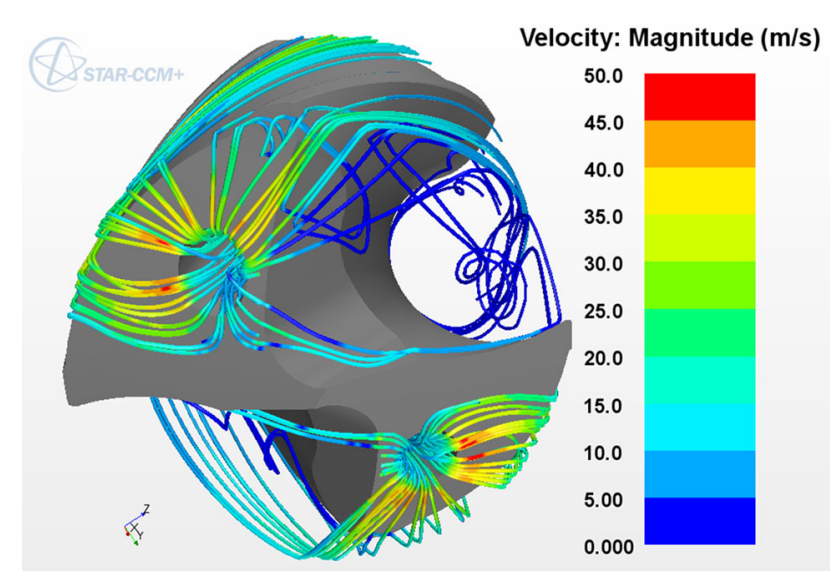

Fig. 17 Direction and magnitude of the $\mathrm{LN}_{2}$ flow velocity around the drill

supply. The diameter and the location of the coolant channels on the drill flank face are two important parameters in drill design channels for fluid supply. In order to evaluate the adequacy of these two parameters for an efficient cooling process, fluid mechanics simulations were performed. Figure 17 shows the direction and velocity of $\mathrm{LN}_{2}$ around the drill, through streamlines. As can be seen, the $\mathrm{LN}_{2}$ flow in the bottom clearance space (space between the clearance or flank drill face and the bottom of the hole being drilled) separates into two principal flows. The first flow goes directly into the chip flute, while the second flow goes through the very narrow gap between the drill body and the wall of the hole being drilled. As a consequence, these flows do not participate in cooling the region adjacent to the major cutting edges, in particular the region adjacent to the drill periphery (zone of high temperatures in Fig. 15), where the fluid is mostly needed. Therefore, to increase the flow through the mentioned region: (1) the bottom clearance space should be increased by modifying the design of the flank face (probably increase the clearance angle); (2) the geometry of the internal channels for fluid supply and its location on the flank face should be modified (they should be placed closer to the major cutting edge and the region adjacent to the drill periphery). If none of these two solutions are sufficient, the flow-rate should also be increased.

\section{Conclusions}

The results show that tool wear generated during cryogenic drilling of IN718 using standard drill optimized for MWF is higher than tool wear generated during drilling using MWF. The two predominant tool wear modes observed in the drills are abrasion and adhesion, which are more intense and accomplished with multiple fractures when $\mathrm{LN}_{2}$ 
is used. These tool fractures are evident in the chisel edge and drill margins, due to the intense thermo-mechanical phenomena observed in these two regions. In general, higher axial force and drilling torque are generated under $\mathrm{LN}_{2}$ cooling when compared to MWF conditions. Since the chisel edge contributes about $60 \%$ for the total axial force, inadequate chisel edge geometry for $\mathrm{LN}_{2}$ cooling can originate an excessive axial force and consequently chisel edge wear and fracture. Moreover, the work material springback and the thermal effects induced by the cooling action will produce hole contraction, which are higher under $\mathrm{LN}_{2}$ cooling when compared to MWF conditions. If the drill does not have sufficient back taper, intense friction forces between the wall of the hole being drilled and the drill margins will be generated, and consequently high drilling torque.

Although the tool temperatures at thermocouple locations 1 and 2 are lower for $\mathrm{LN}_{2}$ when compared to MWF, the predicted maximum temperature is only $8 \%$ lower for the $\mathrm{LN}_{2}$. The most important change when MWF is replaced by LN2 is the reduction of the tool region affected by higher temperatures. This may be the mainly advantage of the LN2 cooling when compared to the MWF, which become crucial as the drilling time or the penetration ratio (thus productivity) increase. Therefore, to take advantage of drilling IN718 under cryogenic cooling conditions, a new drill design is required. The following recommendations should be taken into account for developing this new design:

- Increase the back taper and decrease the margins width to reduce the friction forces between the wall of the hole being drilled and the drill margins, thus reduce the drilling torque.

- Re-design the chisel edge geometry to reduce the axial force, thus increase the drill penetration rate and consequently productivity.

- Increase the bottom clearance space by modifying the flank face design (including increase the clearance angle).

- Modify the geometry of the internal channels for fluid supply and its location on the flank face.

In addition to the previous tool design recommendations, the selection or development of tool materials suitable to work under a wide temperature range from $-196{ }^{\circ} \mathrm{C}$ to very high temperatures is necessary. In particular, a carbide substrate more resistance to the thermal shocks (higher toughness) will contributes to reduce tool fracture. Finally, the increase of $\mathrm{LN}_{2}$ flow-rate may also be required.
Acknowledgments The authors would like to thank MECACHROME for the financial support and making the cryogenic system available to perform the drilling tests. Thank you also ZOLLER and Ecole Nationale d'Ingénieurs de Saint Etienne (ENISE) for providing the tool inspection and tool scanning, respectively. We would like also to thank Prof. Viktor Astakhov to share with us his valuable knowledge on drilling and to Dr. Pierre Naisson for conducting the drilling temperature measurements.

\section{References}

1. Hong SY, Markus I, Jeong W (2001) New cooling approach and tool life improvement in cryogenic machining of titanium alloy Ti-6Al-4V. Int J Mach Tools Manuf 41:2245-2260

2. Khan AA, Ahmed MI (2008) Improving tool life using cryogenic cooling. J Mater Process Technol 196:149-154

3. Pusavec F, Hamdi H, Kopac J, Jawahir IS (2011) Surface integrity in cryogenic machining of nickel based alloy-Inconel 718. J Mater Process Technol 211:773-783

4. Jawahir IS, Brinksmeier E, M'Saoubi R, Aspinwall DK, Outeiro JC, Meyer D et al (2011) Surface integrity in material removal processes: recent advances. CIRP Ann 60:603-626

5. Pu Z, Outeiro JC, Baptista AC, Dillon OW Jr, Puleo DA, Jawahir IS (2012) Enhanced surface integrity of AZ31B Mg alloy by cryogenic machining towards improved functional performance of machined components. Int J Mach Tools Manuf 56:17-27

6. Astakhov VP (2014) Drills: science and technology of advanced operations. CRC Press, Boca Raton

7. Johnson GR, Cook WH (1985) Fracture characteristics of three metals subjected to various strains, strain-rates, temperatures and pressures. Eng Fract Mech 21:31-48

8. Fabre D (2013) Characterization of cutting tool wear in cryogenically assisted machining of Inconel 718. Master's Thesis, Ecole Nationale d'Ingenieurs de Saint-Etienne (ENISE)

9. Zorev NN (1966) Metal cutting mechanics. Pergamon Press, Oxford

10. Courbon C, Pusavec F, Dumont F, Rech J, Kopac J (2014) Influence of cryogenic lubrication on the tribological properties of Ti6Al4V and Inconel 718 alloys under extreme contact conditions. Lubr Sci 26:315-326

11. Zemzemi F, Rech J, Ben Salem W, Dogui A, Kapsa P (2014) Identification of friction and heat partition model at the tool-chipworkpiece interfaces in dry cutting of an Inconel 718 alloy with CBN and coated carbide tools. Adv Manuf Sci Technol 38:5-22

12. Barron RF, Nellis G, Pfotenhauer JM (1999) Cryogenic heat transfer. CRC Press, Boca Raton

13. Richards PBPDG (2008) Simulation of the effectiveness of dynamic cooling for controlling residual stresses in friction stir welds. In: 7th International friction stir welding symposium 20 Sep 2008-22 Sep 2008 UK TWI 2008

14. Hong SY, Ding Y (2001) Cooling approaches and cutting temperatures in cryogenic machining of Ti-6Al-4V. Int J Mach Tools Manuf 41:1417-1437

15. Astakhov VP (2006) Tribology of metal cutting. Elsevier, London

16. Duchosal A, Serra R, Leroy R (2014) Numerical study of the inner canalization geometry optimization in a milling tool used in micro quantity lubrication. Mech Ind 15:8

17. Star CCM+ User Guide, CD-adapco, 2014 